\title{
1. Introduction to private security providers and state responsibility
}

\subsection{RELIANCE ON PRIVATE SECURITY PROVIDERS}

\subsubsection{State Responsibility and New Trends in the Privatization of Warfare}

They operate where states deploy their soldiers or send their diplomatic dignitaries. They are present where companies rely on ground staff in high-risk environments and where aid organizations employ local aid workers despite security risks. Their work environments are diverse, from the Iraqi desert to the mountains of Afghanistan, from the once pirate-infested waters off the coast of Somalia to the jungles of Honduras.

Private security forces are a reality in today's complex environments. They provide security where governments are unwilling or unable to offer protection. In their existence between the public and private sphere, they are sometimes misunderstood as agents of the government. ${ }^{1}$ Private security forces are perceived as operating a shadow business, occasionally portrayed as blood-thirsty, greedy mercenaries. ${ }^{2}$ Headlines denouncing the reliance on mercenaries promise high ratings, causing self-proclaimed investigative journalists to write catchy reports about guns for hire. ${ }^{3}$

1 On these misunderstandings: Lisa Rimli and Susanne Schmeidl, Private Security Companies and Local Populations: An Exploratory Study of Afghanistan and Angola (Swisspeace 2007) 27. On the illustrious example of Jonathan Keith 'Jack' Idema: Robert Young Pelton, Licensed to Kill: Hired Guns in the War on Terror (Three Rivers Press 2007) 227-250.

2 Labelling the contractors as 'shadow forces' and providing an overview of the private military industry: David Isenberg, Shadow Force: Private Security Contractors in Iraq (Praeger Security International 2009) 14ff.

3 Heavily criticizing the reliance on 'mercenaries': Sam Raphael, Mercenaries Unleashed: The Brave New World of Private Military and Security Companies (War on Want 2016) 1-16; Fabien Mathieu and Nick Dearden, Corporate Mercenaries: The Threat of Private Military and Security Companies (War on Want 2006) 1-24. 
The study of the involvement of private actors in modern day warfare has been en vogue since the wars in Iraq and Afghanistan catalyzed the growth of the private security industry and enabled the public to gain insights into this long-ignored conflict reality. Yet, research of this 'anecdote-rich and hard-data poor' ${ }^{4}$ field often remains limited to a reassessment of scandals and a binary good vs. evil classification of actors in armed conflicts. ${ }^{5}$

Privatization of security is often seen as undermining the post-Westphalian order we lived in over the past few centuries. In this order, the supposition is that sovereign states hold the monopoly over the use of force. ${ }^{6}$ Yet, some authors suggest that we are currently returning to the status quo ante-meaning an international order dominated by various actors, not primarily sovereign states — and are moving towards a period that could be termed neomedieval. ${ }^{7}$ This is a highly relevant question given the predominance of multinational corporations (MNCs) and their influence on world affairs. ${ }^{8}$ Adding this to the availability of private armies for hire only further accentuates the necessity to understand this phenomenon.

There is no end to privatization in sight. On the contrary, throughout the major conflicts with United States (US) involvement, reliance on private contractors increased from $10 \%$ in World War II to $50 \%$ during the war in Iraq. ${ }^{9}$ In 2010, for the first time, more contractors were killed on the battle-

4 Joanna Spear, Market Forces: The Political Economy of Private Military Companies (Fafo 2006) 41.

5 Or as Isenberg elegantly put it: 'It is a sad fact that much of the debate over private military and security contractors is, to borrow from Macbeth, a tale told by idiots, full of sound and fury; signifying nothing.': Isenberg (n 2) ix.

6 Sean McFate, The Modern Mercenary: Private Armies and What They Mean for World Order (OUP 2014) 6. On Jellinek's three elements theory (Drei-Elemente-Lehre) and the use of force as an attribute of state sovereignty: Georg Jellinek, Allgemeine Staatslehre (3rd edn, Springer 1922) 353-434. More on the monopoly over the use of force focusing on the exercise of policing powers: Walter Kälin, Andreas Lienhard and Judith Wyttenbach, Auslagerung von sicherheitspolizeilichen Aufgaben (Helbing Lichtenhahn Verlag 2007) 3-18. Arguing that states are free in the choice of their means so long as they are capable of upholding their international legal obligations: Chia Lehnardt, Private Militärfirmen und völkerrechtliche Verantwortlichkeit: Eine Untersuchung aus humanitär-völkerrechtlicher und menschenrechtlicher Perspektive (Mohr Siebeck 2011) 75-76.

7 Hedley Bull, The Anarchical Society: A Study of Order in World Politics (4th edn, Palgrave Macmillan 2012) 254; McFate, The Modern Mercenary (n 6) 72-89; Philip G. Cerny, 'Neomedievalism, Civil War and the New Security Dilemma: Globalisation as Durable Disorder' (1998) 1 Civil Wars 36.

8 Sean McFate, The New Rules of War: Victory in the Age of Durable Disorder (HarperCollins 2019).

9 McFate, The Modern Mercenary (n 6) 19. 
field than US military personnel. ${ }^{10}$ Given the industry trend, this will likely prove to be a recurring phenomenon. New players from rising powers, such as Chinese private security contractors, are expanding their operations overseas. ${ }^{11}$ Moreover, the increasing complexity of weapons technologies creates the necessity for specialized knowledge to operate and maintain the weapons, further adding to the importance of private actors in warfare. ${ }^{12}$ Meanwhile, war weary societies disapprove of government action that leads to coffins of their nation's soldiers returning home. ${ }^{13}$ Reliance on private contractors circumvents this problem while offering the benefit of plausible deniability. ${ }^{14}$ Because of this plausible deniability and in light of the frequent claim of an existing 'responsibility gap', ${ }^{15}$ some term the reliance on private contractors

10 ibid 20. More in: Commission on Wartime Contracting in Iraq and Afghanistan, Final Report to Congress, Transforming Wartime Contracting: Controlling Costs, Reducing Risks, August 2011, 2.

11 Reports suggest rapid growth of the industry throughout the past years: Yang $\mathrm{Zi}$, 'China's Private Security Companies: Domestic and International Roles' (2016) 16 China Brief [https://jamestown.org/program/chinas-private-security-companies -domestic-international-roles/] accessed 4 May 2018; Charles Clover, 'Chinese Private Security Companies Go Global' Financial Times (London, 26 February 2017) [https:// www.ft.com/content/2a1ce1c8-fa7c-11e6-9516-2d969e0d3b65] accessed 1 May 2018; Helena Legarda and Meia Nouwens, 'Guardians of the Belt and Road: The Internationalization of China's Private Security Companies', MERICS China Monitor, [https://www.merics.org/sites/default/files/2018-08/180815_ChinaMonitor_Guardians final.pdf] accessed 10 August 2019.

12 Eugenio Cusumano, 'Policy Prospects for Regulating Private Military and Security Companies' in Francesco Francioni and Natalino Ronzitti (eds), War by Contract: Human Rights, Humanitarian Law, and Private Contractors (OUP 2011) $11-36,12$.

13 Stressing the advantage of private contractors: Oliver R. Jones, 'Implausible Deniability: State Responsibility for the Actions of Private Military Firms' (2009) 24 Connecticut Journal of International Law 239, 257; Steven L. Schooner and Collin D. Swan, 'Dead Contractors: The Un-Examined Effect of Surrogates on the Public's Casualty Sensitivity’ (2012) 6 Journal of National Security Law \& Policy 11.

14 Deborah Avant, 'Selling Security: Trade-Offs in State Regulation of the Private Security Industry' in Thomas Jäger and Gerhard Kümmel (eds), Private Military and Security Companies: Chances, Problems, Pitfalls and Prospects (VS Verlag 2007) 419, 436; Jones (n 13) 256.

${ }_{15}$ Arguing that there is a 'general absence of law within this critical realm' and misunderstanding the complexity of the web of existing national as well as international regulatory provisions applicable to private contractors: Peter W. Singer, 'War, Profits, and the Vacuum of Law: Privatized Military Firms and International Law' (2004) 42 Columbia Journal of Transnational Law 521, 524. For an overview over the actual regulatory environment: Chapter 2.2. 
'tactical privatization', as it sometimes occurs not for economic but political benefit. ${ }^{16}$

The privatization of security is symptomatic of an ongoing shift in international relations, whereby nation states are no longer the sole and predominant actors. ${ }^{17}$ Non-state actors are involved in most of today's conflicts and ignoring their role in this complex security environment would mean turning a blind eye to a prevalent security trend.

While outcries over the erosion of state sovereignty might be premature, there is an adamant risk that governments rely on the private sector to prevent legal responsibility for breaches of international law. Determining when the state is responsible for the conduct of private individuals is a much-debated issue. Indeed, there have been numerous studies on state responsibility for the acts of private individuals and also for the acts of private military and security contractors. However, those were primarily focused on the traditional roles of the contractors, ranging from logistical support to the provision of static and mobile security services. ${ }^{18}$ If the contractors are located remotely and program weapon systems or operate armed drones, this raises completely new questions in the context of state responsibility. This book therefore examines whether

16 Jon D. Michaels, 'Beyond Accountability: The Constitutional, Democratic, and Strategic Problems with Privatizing War' (2004) 82 Washington University Law Quarterly 1001, 1037-1038.

17 More on this trend and resulting policy implications: Walter C. Clemens Jr., Complexity Science and World Affairs (SUNY Press 2013) 14; Anne-Marie Slaughter, The Chessboard and the Web: Strategies of Connection in a Networked World (Yale UP 2017) 23.

18 For general assessments of state responsibility for the conduct of private contractors involved in the more 'traditional' roles: Carsten Hoppe, 'Passing the Buck: State Responsibility for Private Military Companies' (2008) 19 EJIL 989; Shannon Bosch, 'Private Security Contractors and State Responsibility: Are States Exempt from Responsibility for Violations of Humanitarian Law Perpetrated by Private Security Contractors?' (2008) 41 The Comparative and International Law Journal of Southern Africa 353; Alexis P. Kontos, "Private" Security Guards: Privatized Force and State Responsibility under International Human Rights Law' (2004) 4 Non-State Actors and International Law 199; Jones (n 13) 239; Hector Entenza, Les obligations et la responsabilité de l'Etat face aux activités des entreprises militaires et de sécurité privées: Etude de droit international des droits de l'homme et de droit suisse (Helbing Lichtenhahn 2016). On the general issue of state responsibility for the conduct of private individuals: Astrid Epiney, Die völkerrechtliche Verantwortlichkeit von Staaten für rechtswidriges Verhalten im Zusammenhang mit Aktionen Privater (Nomos Verlagsgesellschaft 1992); Olivier de Frouville, 'Attribution of Conduct to the State: Private Individuals' in James Crawford, Alain Pellet, Simon Olleson and Kate Parlett (eds), The Law of International Responsibility (OUP 2010) 257; Alexander Kees, 'Responsibility of States for Private Actors' MPEPIL (2011). 
the current state responsibility regime sufficiently addresses the reliance on private contractors, particularly in the context of new trends in warfare.

\subsubsection{What are PMSCs?}

Before delving into debates about the current state responsibility regime, it is essential to understand which types of companies will be assessed. A vast range of definitions is employed to describe the private security industry. The industry, associated lobby groups as well as governments predominantly use the term 'Private Security Companies' (PSCs). ${ }^{19}$ PSCs include companies, which provide an 'activity directly related to protecting a "noun", ${ }^{20}$ meaning a person or an object. Non-Governmental Organizations (NGOs) and human rights activists often employ the term 'Private Military Company' (PMC) ${ }^{21}$ or even refer to the companies as mercenaries. ${ }^{22}$ The industry is critical of the term 'PMC', arguing that it does not fall under this classification as the services offered are purely defensive. ${ }^{23}$ In academia, the term frequently used is 'Private Military and Security Companies' (PMSCs).

Among the most famous typologies and definitions is Singer's 'Tip of the Spear', ${ }^{24}$ attempting to mirror military units by classifying the companies as either Military Provider Firms, Military Consultant Firms or Military Support Firms ${ }^{25}$ while applying the overall label 'Private Military Firms' (PMF). Though the focus on the function of the companies is a logical way to break down the industry, the definition Singer uses for PMF is problematic. He defines PMFs as 'private business entities that deliver to consumers a wide

19 Existing standards, codes of conduct and best practice agreements refer to Private Security Companies, Private Security Providers or Private Security Operators. For more see: ISO 18788: Management System for Private Security Operations Requirements with Guidance for Use (ISO 2015).

20 Referring to the definition by Doug Brooks, President Emeritus of the International Stability Operations Association (ISOA): McFate, The Modern Mercenary (n 6) 10.

${ }_{21}$ Hin-Yan Liu, Law's Impunity: Responsibility and the Modern Private Military Company (Hart Publishing 2015) 1; Chia Lehnardt, 'Individual Liability of Private Military Personnel under International Criminal Law' (2008) 19 EJIL 1015.

22 Relying on both the terms 'modern mercenary' and PMC: McFate, The Modern Mercenary (n 6) 1.

23 This argument was made by industry representatives at the Annual General Assembly of the International Code of Conduct Association (ICoCA) on October 12, 2017.

24 Peter Singer, Corporate Warriors: The Rise of the Privatized Military Industry. Updated Edition (CUP 2007) 91.

25 ibid. 
spectrum of military and security services, once generally assumed to be exclusively inside the public context. ${ }^{26}$

Yet, he falls short of defining 'public context'. Legal scholars might understand this as inherently governmental functions or elements of governmental authority. It remains unclear whether this was what Singer intended to imply. As some countries forbid private contractors from performing inherently governmental functions, this clarification would be instrumental. The definition, though a good starting point, is thus too vague to be helpful for a succinct legal analysis.

Another typology is offered by McFate based on the three categories of US Army military units depending on their mission or function. ${ }^{27} \mathrm{He}$ distinguishes PMCs, Security Support Companies and General Contractors. Based on this typology, PMCs are the private sector equivalent of combat arms - units of the military in charge of killing enemies abroad or training others to kill, typically a job of the infantry or special forces but also including armed aviation and armor. ${ }^{28}$ Security Support Companies are McFate's equivalent to combat service units, which are charged with operational support to combat arms units and only engage the enemy in self-defense, such as the military police or military intelligence. ${ }^{29}$ Finally, General Contractors are the private sector version of combat service support, providing functions ranging from logistical to administrative support, roles typically performed by the quartermaster or medical services corps. ${ }^{30}$ This typology offers a lot of insight into the way the industry is structured, but in its specificity also lies the vital flaw, as some companies cross the lines between different roles. For example, while McFate classifies DynCorp International as General Contractors, primarily providing logistical assistance, he himself trained foreign militaries while he worked for DynCorp. ${ }^{31}$ The typology is thus useful for a first insight but does not sufficiently address the complexity of the industry. Many companies offer a broad range of services and are not easily categorized. Instead, a more fluid concept is necessary, allowing companies to fall into several categories depending on the respective contract.

Avant focused on the contracts instead of the companies as units of analysis. ${ }^{32}$ She distinguished the services offered by the companies between

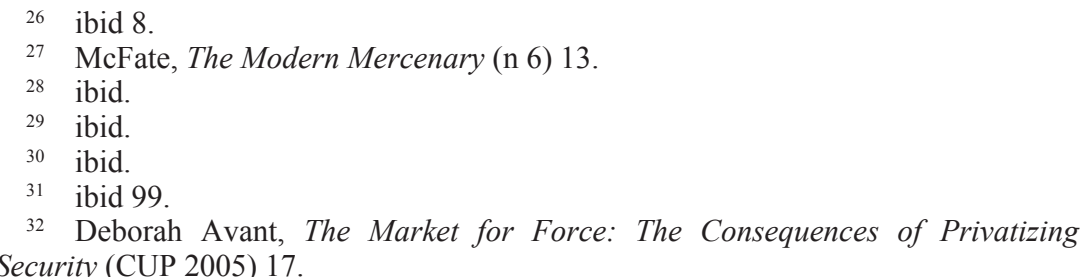
Security (CUP 2005) 17. 
those providing external security, those protecting the border through 'operational support, military advice and training, and logistical support ${ }^{33}$ as well as those providing internal security, focused on 'site security (armed and unarmed), crime prevention, and intelligence'. ${ }^{34}$ However, this differentiation is insufficient for two reasons: first, it centers on governments as customers $^{35}$ and second, its clear distinction between the external and internal provision of security services can no longer be upheld because technological advances allow remote operations, such as through unmanned aerial vehicles (UAVs). ${ }^{36}$ This possibility of remote operations also highlights the flaws of the often-quoted 'tip of the spear' logic. While the geographical proximity to the battlefield certainly indicates the danger to individual contractors, it is not a sufficient indicator for their contribution to active combat missions.

Hereafter, the distinctions made will be according to the geographical proximity to the battlefield as well as the contribution to active combat missions, while using contracts instead of companies as the units of analysis. This approach is visualized in Figure 1.1, which shows the Adapted Tip of the Spear, an approach created in this book based on analysis of other approaches.

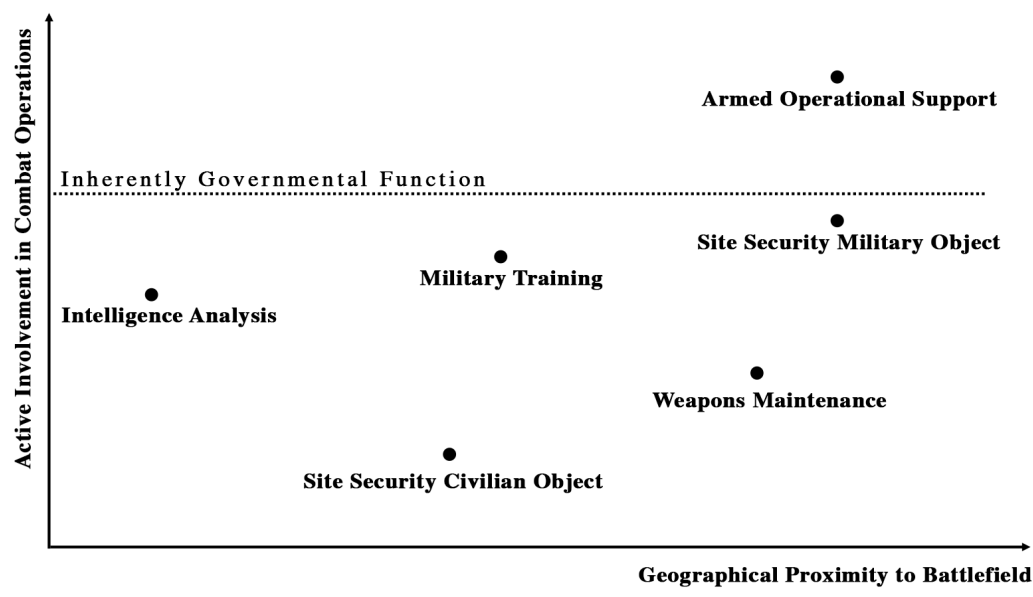

Figure 1.1 Adapted Tip of the Spear

Note: Graph designed by author.

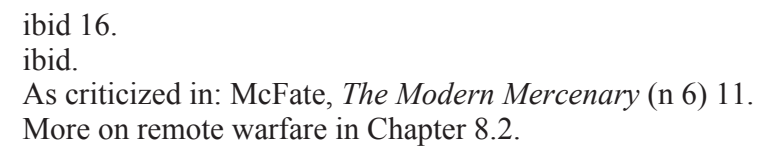


Following a more general approach, the Montreux Document, a multi-stakeholder initiatives (MSI) launched by the International Committee of the Red Cross (ICRC) and the Swiss Federal Department of Foreign Affairs (FDFA), subsumes the private security industry under the term PMSC, defined as follows:

'PMSCs' are private business entities that provide military and/or security services, irrespective of how they describe themselves. Military and security services include, in particular, armed guarding and protection of persons and objects, such as convoys, buildings and other places; maintenance and operation of weapons systems; prisoner detention; and advice to or training of local forces and security personnel. ${ }^{37}$

The merit of this definition is that it includes companies irrespective of whether they provide military or security services. As the outcome of an MSI, this definition is a compromise between the different stakeholders involved in the negotiations. The definition lacks the specificity provided in the function-based definitions of Singer and McFate. Yet, this approach is noteworthy as many companies offer a range of functions and might therefore fall into more than one category. The term PMSC is thus the most inclusive, which makes up for the loss of specificity. Given the goal of assessing outsourcing of a wide range of functions to companies providing military or security services, the terminology PMSC will be used in this book, adapted in the following way:

PMSCs are private business entities that provide military and/or security services, sometimes even considered inherently governmental functions, irrespective of how they describe themselves. Military and security services include, in particular, the provision of static and mobile protection; programming, maintenance and operation of weapon systems, whether remotely or on the ground; prisoner detention; advice to or training of local forces and security personnel; participation in military missions, whether employed by nation states, international organizations, private sector clients or non-state actors.

\subsubsection{Different Relations between States and PMSCs}

When considering the question of state responsibility and especially the due diligence obligations states have with regards to their reliance on PMSCs, it is necessary to understand the relationship between the state and the PMSC. The

37 The Montreux Document: 'On Pertinent International Legal Obligations and Good Practices for States Related to Operations of Private Military and Security Companies During Armed Conflict of 17 September 2008' 9. 
distinction suggested by the Montreux Document is between home states, contracting states as well as territorial states. These states are defined as follows:

'Home States' are States of nationality of a PMSC, i.e. where a PMSC is registered or incorporated; if the State where the PMSC is incorporated is not the one where it has its principal place of management, then the State where the PMSC has its principal place of management is the 'Home State'. ${ }^{38}$

'Contracting States' are States that directly contract for the services of PMSCs, including, as appropriate, where such a PMSC subcontracts with another PMSC. ${ }^{39}$

'Territorial States' are States on whose territory PMSCs operate. ${ }^{40}$

For the purpose of this study, territorial states encompass not only those states on whose territory PMSCs operate but also those states on whose territory the results of the contractors' actions occur. As the case studies will show, this is necessary to categorize states affected by remote warfare.

As is already indicated in the definition of the contracting state, subcontracting makes it more difficult to determine the relationship between the PMSC and the state. The following graph provides a simplified overview of the different relationships states have with PMSCs.

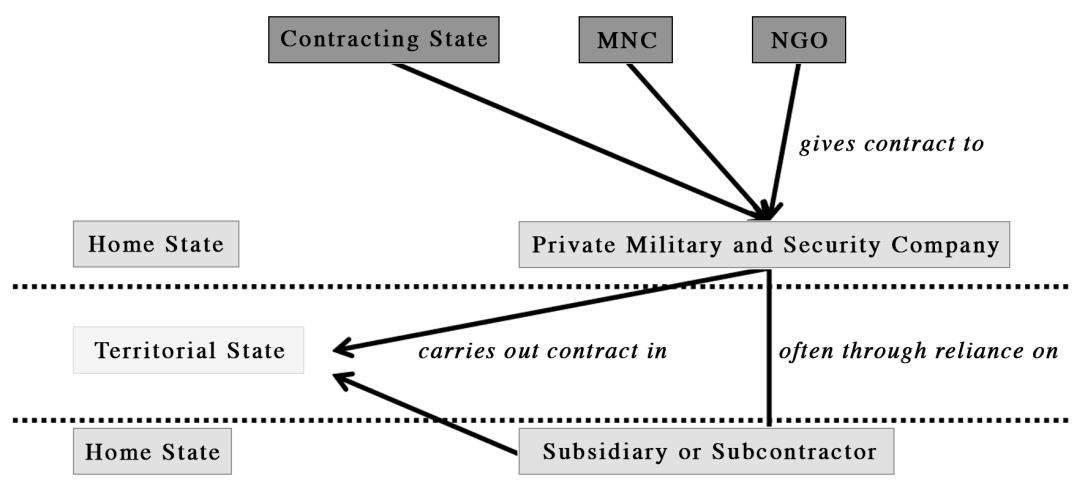

Figure 1.2 PMSC-State Relations

Note: Figure designed by author.

Montreux Document (n 37), Preface.

ibid.

40 ibid. 
However, in most cases, an even more complex web of relationships and differing scenarios are possible. In some cases, the home state of the subsidiary or subcontractor can be equivalent to the territorial state, meaning that a PMSC is hiring a local company for basic guard functions, while the management is provided by the foreign PMSC. In other cases, the home state of the PMSC might be the contracting state as well, which is predominantly the case when governments are relying on private contractors to support their operations in conflict zones overseas. Moreover, the home state can be the territorial state if the contracting state is completely relying on a local PMSC. In another scenario, the contracting state is also the home state and territorial state if a country hires a PMSC to perform functions on its territory. However, this domestic scenario is not the main focus.

\subsection{GAPS IN THE STATE RESPONSIBILITY REGIME?}

The desire to hold someone responsible is a baseline of the legal system. Complex legal regimes determine responsibility in the areas of torts, crimes and public law on a national level. Yet, the question of responsibility is more intricate on the international level. ${ }^{41}$

Establishing situations where states can be held responsible for violations of international legal obligations in relation to the reliance on private contractors is more than a theoretical exercise. If state responsibility can be established, other states can claim reparation and remedies. The private security industry is prone to jurisdictional challenges which can prevent individuals from receiving reparations for damages they suffered. ${ }^{42}$ But while companies can rebrand or avoid responsibility by relocating headquarters to another jurisdiction, nation states are steadier actors on the international sphere. Moreover, governments continue to be among the prime clients of the private security industry. Therefore, state responsibility can serve as an alternate path towards justice, although this path is only open to states. ${ }^{43}$

\footnotetext{
41 John J. Mearsheimer, The Tragedy of Great Power Politics (updated edn, W. W. Norton \& Company 2014) 30.

42 On the challenges of litigating cases concerning private contractors: Cedric Ryngaert, 'Litigating Abuses Committed by Private Military Companies' (2008) 19 EJIL 1035; Michael Hurst, 'After Blackwater: A Mission-Focused Jurisdictional Regime for Private Military Contractors During Contingency Operations’ (2008) 76 The George Washington Law Review 1308.

43 On the differences between state responsibility, corporate responsibility and individual responsibility see Chapter 3.4.
} 
However, there are several challenges to establishing state responsibility for the acts of private contractors. In general, states are only responsible for the acts of their agents, not for the acts of private individuals. ${ }^{44}$ When relying on the military or other officials, states must provide remedies for violations of international law committed by those actors. Yet, when relying on the private sector, states might be able to avoid providing these remedies, not only because states can deny their involvement, but also because those actors are not state organs. ${ }^{45}$ It is therefore important to identify the situations in which the acts of private contractors can be attributed to a state to diminish the benefits states could achieve should they pursue 'tactical privatization'. ${ }^{46}$

Even if the acts cannot be attributed to the state it must be studied whether the state has due diligence obligations, which require it to sufficiently regulate the private security industry, investigate potential violations and prosecute the perpetrators. This raises many questions concerning not only the extent of the state's due diligence obligations but also jurisdiction, extraterritorial application of legal norms and the interplay of the obligations of different states.

Finally, it has to be assessed whether outsourcing certain functions can be considered a violation of international legal obligations, if international law explicitly or implicitly prohibits it.

Given the complexity of the state responsibility regime as well as the prevalent reliance on private contractors in complex environments, it is necessary to sufficiently limit the scope of this book to allow an in-depth analysis. Different phases of research on private security providers occurred over the past few years. ${ }^{47}$ In the early phase, research largely centered around debates about the legality of reliance on private contractors and the applicability of existing anti-mercenary regulation. ${ }^{48}$ Thereafter, scholars and practitioners attempted

44 More on the basics of attribution in Chapter 5.1.

45 An exception is the violation of human rights law. States have to offer remedies also in cases of violations of human rights by private actors. More on the violation of human rights law and the state's obligations in Chapter 4.4.

46 Jones (n 13) 258.

47 For an initial overview of those phases: Mirko Sossai, 'Combatting the Legal Side Effects of Privatized War' (Völkerrechtsblog, 9 October 2017) [http:// voelkerrechtsblog.org/combatting-the-legal-side-effects-of-privatized-war/] accessed 4 May 2018. Commenting on Sossai's contribution: Frauke Renz, 'Quo Vadis PMSC?' (Völkerrechtsblog, 4 December 2017) [https://voelkerrechtsblog.org/quo-vadis-pmsc/] accessed 4 May 2018.

48 On mercenary regulation and the question whether private contractors might be considered modern-day mercenaries: Antenor Hallo de Wolf, Reconciling Privatization with Human Rights (Intersentia 2012) 465-480. More on how anti-mercenary regulation might apply to PMSCs: Sarah Percy, 'Mercenaries: Strong Norm, Weak Law' (2007) 61 International Organization 367; Erica L. Gaston, 'Mercenarism 2.0? The Rise of the Modern Private Security Industry and Its Implications for International 
to find ways to regulate PMSCs on an international level. ${ }^{49}$ This was followed by an attempt to understand whether international humanitarian law (IHL) and international human rights law (IHRL) required thorough regulation of the industry on a national level. ${ }^{50}$ In the next phase, legal scholarship shifted towards a focus on regulatory gaps and ways to reform national legal systems to avoid impunity of contractors. ${ }^{51}$ Lately, the debate has transitioned to examining the role of MSI. ${ }^{52}$ Most of the existing legal scholarship has been limited to the functions private contractors performed during the height of the wars in Afghanistan and Iraq, namely the protection of personnel and objects. Moreover, research was largely limited to a focus on contracting states, particularly the United States and the United Kingdom (UK). ${ }^{53}$

This book aims to bring the focus back to international legal obligations and how these obligations relate to questions of state responsibility. Moreover, this book covers the responsibility of not only contracting states but also home states and territorial states.

Humanitarian Law Enforcement' (2008) 49 Harvard International Law Journal (2008) 221; Ulrich Petersohn, 'Reframing the Anti-Mercenary Norm: Private Military and Security Companies and Mercenarism' (2014) 69 International Journal 475.

49 Nigel D. White, 'The Privatisation of Military and Security Functions and Human Rights: Comments on the UN Working Group's Draft Convention' (2011) 11 Human Rights Law Review 133; Caroline Holmqvist, Private Security Companies: The Case for Regulation (SIPRI 2005) $45 \mathrm{ff}$.

50 For a comprehensive overview of regulation: Christine Bakker and Mirko Sossai (eds), Multilevel Regulation of Military and Security Contractors: The Interplay between International, European and Domestic Norms (Hart 2012); Holmqvist (n 49) $50-55$.

51 On the fears of contractor impunity and accountability gaps: Steven Paul Cullen, 'Out of Reach: Improving the System to Deter and Address Criminal Acts Committed by Contractor Employees Accompanying Armed Forces Overseas' (2009) 38 Public Contract Law Journal 509; Benjamin Perrin, 'Mind the Gap: Lacunae in the International Legal Framework Governing Private Military and Security Companies' (2012) 31 Criminal Justice Ethics 213; Ryngaert (n 42) 1035-1053.

52 See Sorcha MacLeod, 'Private Security Companies and Shared Responsibility: The Turn to Multistakeholder Standard-Setting and Monitoring through Self-Regulation"Plus"' (2015) 62 Netherlands International Law Review 119; Renée de Nevers, '(Self) Regulating War?: Voluntary Regulation and the Private Security Industry' (2009) 18 Security Studies 479.

53 This focus is understandable given the size of the industry in the United States and the UK. Moreover, there is greater transparency with regards to the extent to which governments have relied on private contractors: Allison Stanger, One Nation under Contract: The Outsourcing of American Power and the Future of Foreign Policy (Yale UP 2009). Another focus was the applicability of the national regulatory frameworks, as discussed in: Jenny S. Lam, 'Accountability for Private Military Contractors under the Alien Tort Statute', (2009) 97 California Law Review 1459. 
The focus of this book is not on the acts of private contractors in all complex environments, which might also include areas recovering from natural disasters ${ }^{54}$ but solely on those during armed conflicts. These are the situations during which fundamental rights are most endangered. In armed conflicts, actors rarely fear the power of local law enforcement agencies. Operating in conflict zones, limited consequences derive from violations of international law. Adding to the complexity, those are also situations where the private security sector is indispensable. Many actors - public and private-rely on private contractors to provide the vital public good of security when no public actor is willing or able to do so. Therefore, the question of when a state can be held responsible for the acts of private contractors during armed conflicts is particularly relevant. While natural disasters can also cause severe distress and create the need for clear rules on state responsibility for reliance on private actors, they trigger different questions. ${ }^{55}$ This study will assess both international armed conflicts (IACs) as well as non-international armed conflicts (NIACs). While post-conflict situations or failed states are also environments where governments rely on the private sector for security services, the specific tasks evaluated in this study are limited to those performed during ongoing armed conflicts.

The classification of conflicts in IHL is based on the dichotomy between an IAC and a NIAC. Most norms address situations of IAC, mainly as IHL was written in the post-Westphalian era where wars were primarily fought between sovereign states. ${ }^{56}$

An IAC requires the use of armed force by a state through its military or private actors against another state in its territory. ${ }^{57}$ There are no requirements regarding duration or territorial expansion and states do not need to

${ }^{54}$ International Code of Conduct of Private Security Providers of 9 November 2015 (ICoC) 5 .

55 An example of reliance on contractors after natural disasters is the aftermath of Hurricane Katrina in the United States in 2005: Erik Prince, Civilian Warriors: The Inside Story of Blackwater and the Unsung Heroes of the War on Terror (Portfolio 2014) 265-269.

56 Dapo Akande, 'Classification of Armed Conflicts: Relevant Legal Concepts', in Elizabeth Wilmshurst (ed), International Law and the Classification of Conflicts (OUP 2012) 40; Nils Melzer, Targeted Killing in International Law (OUP 2008) $244 \mathrm{ff}$.

57 Geneva Convention for the Amelioration of the Condition of the Wounded and Sick in Armed Forces in the Field of 12 August 1949, UNTS Vol. 75, I-970; Geneva Convention for the Amelioration of the Condition of Wounded, Sick and Shipwrecked Members of Armed Forces at Sea of 12 August 1949, UNTS Vol. 75, I-971; Geneva Convention Relative to the Treatment of Prisoners of War of 12 August 1949, UNTS Vol. 75, I-972; Geneva Convention Relative to the Protection of Civilian Persons in Time of War of 12 August 1949, UNTS Vol. 75, I-973, Common Art. 2. 
formally declare war. ${ }^{58}$ This book follows Pictet's 'first shot theory' arguing that no formal declaration of war is necessary but that every hostile act or a single wounded person is sufficient to trigger the application of the Geneva Convention (GC). ${ }^{59}$ This view was upheld by the International Criminal Tribunal for the former Yugoslavia (ICTY) in the 1995 Tadic Interlocutory Appeal. ${ }^{60}$ As the goal of IHL is to minimize suffering during conflicts, assuming a higher threshold of violence is not convincing. ${ }^{61}$

The more difficult question is determining the NIAC threshold. Originally, NIACs were only regulated in Common Art. 3 GC I-IV; now there are different categories of NIACs. Understanding NIACs has become essential as today they are more frequent than IACs. ${ }^{62}$ Conflict scenarios have become more complex, involving not only armed groups and foreign governments intervening alongside civilian populations, but also private contractors. ${ }^{63}$ Fortunately, IHL recognizes the possibility of categorizing conflicts as internationalized or mixed conflicts with both international and non-international components. ${ }^{64}$

An ICRC study on customary international law suggested that customary international law applicable during NIAC now incorporates numerous norms originally addressing IACs. ${ }^{65}$ In this book, all types of IACs and NIACs will be assessed, whereas conflicts falling below the lowest threshold of NIACs will not be included. Internal disturbances and tensions, including riots or isolated

58 ICRC, Commentary on the First Geneva Convention: Convention (I) for the Amelioration of the Condition of the Wounded and Sick in Armed Forces in the Field (updated commentary, ICRC 2016) paras 202, 210-211.

59 Jean S. Pictet, The Geneva Conventions of 12 August 1949: Commentary, First Geneva Convention for the Amelioration of the Condition of the Wounded and Sick in Armed Forces in the Field (ICRC 1952) 32.

${ }^{60}$ ICTY, Prosecutor v. Dusko Tadić a/k/a 'Dule', IT-94-1, Appeals Chamber, Decision on the Defense Motion for Interlocutory Appeal on Jurisdiction, 2 October $1995 \S 70$.

${ }^{61}$ On the goal of IHL to mitigate suffering: Antonio Cassese, 'Current Challenges to International Humanitarian Law' in Andrew Clapham and Paola Gaeta (eds), The Oxford Handbook of International Law in Armed Conflict (OUP 2014) 5.

62 For a detailed study of conflict trends: Marie Allansson, Erik Melander and Lotta Themnér, 'Organized Violence, 1989-2016' (2017) 54 Journal of Peace Research 574, $575 \mathrm{ff}$.

${ }_{63}$ Vincent Bernard, 'Delineating the Boundaries of Violence' (2014) 96 IRRC 5.

64 David Turns, 'The Law of Armed Conflict (International Humanitarian Law)' in Malcolm D. Evans (ed), International Law (OUP 2014) 821, 827.

65 Jean-Marie Henckaerts and Louise Doswald-Beck (eds), Customary International Humanitarian Law, Volume II: Practice (CUP 2005). More on this issue in: Kreß (n Claus Kreß, 'Towards Further Developing the Law of Non-International Armed Conflict: A Proposal for a Jus in Bello Interno and a New Jus Contra Bellum Internum' (2014) 96 IRRC 30-44.) 33. 
and sporadic acts of violence, are below the threshold of a NIAC according to Common Art. 3 GC I-IV. ${ }^{66}$

Questions about state responsibility become relevant when international legal obligations are violated; however, an analysis of the wide spectrum of international legal obligations would exceed the scope of this work. Thus, the focus will be on those rights which are most at risk during armed conflicts: the core non-derogable human rights as well as IHL. In emergencies, states can derogate from several human rights norms. ${ }^{67}$ Since conflicts classify as emergencies, the focus of this study will solely be on the non-derogable human rights. ${ }^{68}$ A particular focus will be on the non-derogable human rights which are also considered jus cogens and particularly relevant with regards to the reliance on private contractors during armed conflict: the prohibition of the arbitrary deprivation of life, torture, genocide and crimes against humanity. ${ }^{69}$

IHL guides behavior during armed conflicts and thus must be respected by all actors, whether public or private, state or non-state. ${ }^{70} \mathrm{GC}$ I-IV, AP I and II to the GC as well as the Hague Convention (IV) of 1907 are especially relevant

66 On the threshold of a NIAC based on Art. 1 Additional Protocol (AP) II: Gary D. Solis, The Law of Armed Conflict: International Humanitarian Law in War (2nd edn, CUP 2016) 163ff; Yves Sandoz, Christophe Swinarski and Bruno Zimmermann (eds), Commentary on the Additional Protocols of 8 June 1977 to the Geneva Conventions of 12 August 1949 (ICRC 1987) N 4464ff.

${ }_{67}$ This is further discussed in Chapter 4.4.

68 Highlighting that conflicts qualify as emergencies which allow for derogation: Robert Kolb and Richard Hyde, An Introduction to the International Law of Armed Conflicts (Hart Publishing 2008) 260ff. Further on non-derogable rights: Walter Kälin and Jörg Künzli, Universeller Menschenrechtsschutz: Der Schutz des Individuums auf globaler und regionaler Ebene (3rd edn, Helbing Lichtenhahn 2013) para 405-406. On the relationship between IHL as lex specialis and IHRL: Marco Sassòli and Laura M. Olson, 'The Relationship Between International Humanitarian and Human Rights Law Where it Matters: Admissible Killing and Internment of Fighters in Non-international Armed Conflicts' (2008) 90 IRRC 599. See further on this: Chapter 4.4.

69 On these norms as common non-derogable norms with jus cogens character: Koji Teraya, 'Emerging Hierarchy in International Human Rights and Beyond: From the Perspective of Non-derogable Rights' (2001) 12 EJIL 917, 927. Discussing the sixteen rights considered non-derogable and named the 'Paris Minimum Standards': Subrata Roy Chowdhury, Rule of Law in a State of Emergency: The Paris Minimum Standards of Human Rights Norms in a State of Emergency (Pinter Publishers 1989) 147ff. Peremptory norms are discussed in more detail in Chapter 4.2.1. While other non-derogable human rights such as the prohibition of imprisonment for failure to fulfill a contractual obligation as enshrined in Art. 11 of the International Covenant on Civil and Political Rights of 16 December 1966, UNTS Vol. 999, I-14668 (ICCPR) are highly important, they are not affected by the reliance on private contractors.

${ }_{70}$ Robert Kolb, Ius in Bello: Le Droit International des Conflits (2nd edn, Helbing Lichtenhahn 2009) 200-211; Solis (n 66) 168ff. 
to the conduct of parties in an IAC as well as a NIAC. ${ }^{71}$ The focus here is on jus in bello and not jus ad bellum.

This study is based on the understanding of state responsibility established by the International Law Commission's (ILC) Articles on State Responsibility (ASR). ${ }^{72}$ The clear focus will thus be on Part One of the ASR, whereby Part Two and Part Three are only discussed when there are significant implications with regards to the reliance on private contractors. ${ }^{73}$

The focus is on private contractors working for governments. While many interesting legal questions arise from contractors working for $\mathrm{MNCs}^{74}$ as well as NGOs, ${ }^{75}$ the resulting questions regarding state responsibility are different. The same goes for the acts of private contractors during peacekeeping missions. ${ }^{76}$ While some parallels exist in the debates concerning the accountability of international organizations such as the United Nations (UN) and the accountability of states, the scope of this work is limited to private contractors

71 More on the conventional sources of IHL, customary international law as well as guiding principles of IHL in: Kolb, Ius in Bello (n 70) 100-122.

72 The ASR were included in the Annex of the UN General Assembly (GA) Resolution 56/83: Responsibility of States for Internationally Wrongful Acts, 28 January 2002, UN Doc. A/RES/56/83.

73 Part One addresses the origin of international responsibility, Part Two deals with the content, form and degrees and international responsibility and the subject of Part Three is the settlement of disputes and implementation of state responsibility. For more details on the structure of the ASR see Chapter 3.2.

74 Extractive industries are particularly reliant on private security provision: Elizabeth Umlas, 'Protected but Exposed: Multinationals and Private Security' in Small Arms Survey 2011: States of Security (CUP 2011) 135-165; Yuliya Zabyelina and Irina Kustova, 'Energy and Conflict: Security Outsourcing in the Protection of Critical Energy Infrastructures' (2015) 50 Cooperation and Conflict 531, 535-537.

75 On the relationship of private security providers and NGOs: Birthe Anders, 'Tree-huggers and Baby-killers: The Relationship between NGOs and PMSCs and its Impact on Coordinating Actors in Complex Operations' (2013) 24 Small Wars \& Insurgencies 278; Christopher Spearin, 'Private, Armed and Humanitarian? States, NGOs, International Private Security Companies and Shifting Humanitarianism' (2008) 39 Security Dialogue 363.

${ }^{76}$ For a discussion about the question of whether the " "borrowing" international organization or the "lending" State' is accountable for the conduct of peacekeepers: Pierre Klein, 'The Attribution of Acts to International Organizations' in James Crawford, Alain Pellet, Simon Olleson and Kate Parlett (eds), The Law of International Responsibility (OUP 2010) 297-315. An excellent overview of all international legal questions related to private contractors and peacekeeping missions: Lindsey Cameron, The Privatization of Peacekeeping: Exploring Limits and Responsibility under International Law (CUP 2017). 
working for government agencies, especially since the ASR do not cover responsibility of international organizations. ${ }^{77}$

This book uses three case studies to determine the applicability of the ASR. Those cases examine contractors analyzing intelligence data, contractors operating armed drones and contractors programming autonomous weapon systems (AWS). The three cases chosen reflect new trends in warfare, ranging from advances in remote warfare to the development of AWS. ${ }^{78}$ Guarding mobile or static assets is the most common case analyzed on the privatization of warfare; this book is, however, limited to new trends in warfare. Similarly, while some claim that maritime security is a new market, this issue has been sufficiently studied and will not be included in this assessment. ${ }^{79}$ There are many other cutting-edge technological advances which lead to governments relying on private contractors. One such area is the cyber domain; though a fascinating research field, responsibility in the cyber domain exceeds the scope of this study. ${ }^{80}$

In general, the only roles of private contractors relevant for the purpose of this book are those closely linked to combat operations. Contractors providing logistics services or assisting the armed forces with food preparation and laundry are not assessed given the different nature of legal challenges arising from their scope of work.

This book analyzes:

- under which conditions the acts of private contractors can be attributed to the contracting state;

- what due diligence obligations contracting, home and territorial states have with regards to the reliance on private contractors;

77 This is laid down in Art. 57 ASR. The ILC issued a separate draft focusing on responsibility of international organizations: ILC, Responsibility of International Organizations, 30 May 2011, UN Doc. A/CN.4/L.778. More on the differences between responsibility of states and responsibility of international organizations: James Crawford and Simon Olleson, 'The Character and Forms of International Responsibility' in Malcolm D. Evans (ed), International Law (4th edn, OUP 2014) 443, 444ff.

78 These two phenomena will be introduced in Chapter 8 .

79 Claiming that maritime security provision is a new market: Entenza (n 18) 4.

80 For a first overview of state responsibility in the context of cyber warfare: Michael N. Schmitt (ed), Tallinn Manual 2.0 on the International Law Applicable to Cyber Operations (CUP 2017) 29-41; Kubo Mačák, 'Decoding Article 8 of the International Law Commission's Articles on State Responsibility: Attribution of Cyber Operations by Non-State Actors' (2016) 21 Journal of Conflict and Security Law 405; Sven-Hendrik Schulze, Cyber-'War': Testfall der Staatenverantwortlichkeit (Mohr Siebeck 2015). 
- whether the outsourcing of certain functions during armed conflicts presents a relevant violation of an international legal obligation.

These questions are examined in light of the new trends in warfare, particularly the reliance on private contractors during drone operations and in the programming of AWS.

To answer the key research questions, this book takes a dualistic analytical approach. First, it examines the rules of state responsibility and how they apply to contracting states, home states and territorial states. Thereafter, this book introduces three case studies to test the applicability of the current state responsibility regime to new trends in warfare. By using both a deductive and inductive methodology, this book assesses the extent of the gaps in the current state responsibility regime. 